\title{
PENGARUH RELIGIUSITAS DAN STATUS SOSIAL EKONOMI ORANG TUA TERHADAP GAYA HIDUP HEDONISME PADA REMAJA
}

\author{
THE EFFECT OF RELIGIUSITY AND SOCIAL ECONOMIC STATUS OF PARENTS ON \\ THE HEART OF LIFE ON HEART OF LIFE
}

NURWITASARI

Fakultas Psikologi, Universitas 17 Agustus 1945 Samarinda

Email : nurwitasari14@gmail.com

\begin{abstract}
Abstrak: Penelitian ini bertujuan untuk membuktikan secara empiris pengaruh religiusitas dan status sosial ekonomi orang tua terhadap gaya hidup hedonisme pada remaja. Sampel dalam penelitian ini adalah siswa dan siswi kelas XI MAN 1 Samarinda yang berusia sekitar 15-17 tahun sebanyak 82 subjek dengan menggunakan teknik sampling random sederhana yaitu dimana setiap elemen populasi mempunyai kesempatan yang sama dan diketahui untuk diseleksi. Metodologi penelitian ini menggunakan kuantitatif korelasional. Data dianalisis dengan regresi linier berganda. Hasil penelitian menunjukkan bahwa ada pengaruh negatif religiusitas terhadap gaya hidup hedonisme pada remaja, atau semakin tinggi religiusitas akan menyebabkan gaya hidup hedonisme pada remaja menurun dengan $t_{\text {hitung }}=-2,790$, dan $p=0,007$. Hasil penelitian status sosial ekonomi orang tua menunjukkan bahwa berpengaruh positif terhadap gaya hidup hedonisme pada remaja, atau semakin tinggi status sosial ekonomi orang tua akan menyebabkan gaya hidup hedonisme pada remaja meningkat dengan $t_{\text {hitung }}=4,580$, dan $p=0,000$. Koefisien regresi (B) variabel $X_{1}$ atau religiusitas sebesar $-0,388$ menyatakan bahwa setiap kali religiusitas ditingkatkan $1 \%$ maka akan menurunkan gaya hidup hedonisme sebesar 0,388\%. Koefisien regresi (B) Status Sosial Ekonomi Orang tua sebesar 1,539 yang artinya bila nilai B status sosial ekonomi orang tua ditingkatkan $1 \%$ maka gaya hidup hedonisme pada remaja meningkat pula $1,539 \%$. Gaya hidup hedonisme pada remaja sebesar $24,2 \%$ dapat di sebabkan oleh pengaruh religiusitas dan status sosial ekonomi orang tua dengan $\mathrm{R}=0,492^{\mathrm{a}}$, dan $R$ Square $=24,2 \%$, sedangkan $75,8 \%$ dapat disebabkan oleh variabel lain.
\end{abstract}

Kata kunci: Religiusitas, status sosial ekonomi, gaya hidup hedonisme.

\begin{abstract}
This study aims to demonstrate empirically the effect of religiosity and socio-economic status of parents of hedonistic lifestyles in adolescents. The sample in this study were students XI MAN 1 Samarinda aged about 15-17 years as many as 82 subjects using simple random sampling technique that is where every element of the population has an equal opportunity to be selected and the unknown. Methodology This study used quantitative correlation. Data were analyzed using linear regression. The results showed that there was a negative effect of religiosity on the lifestyle of hedonism in adolescents, or the higher the religiosity will cause the lifestyle of hedonism in adolescents declined by $t=-2,790$, and $p=0.007$. Results of the study of socio-economic status of parents showed that the positive effect on the lifestyle of hedonism in adolescents, or the higher the socio-economic status of parents will lead to a lifestyle of hedonism in adolescents increases with $t=$ 4,580 , and $p=0,000$. Regression coefficient $(B)$ variable $X_{1}$ or religiosity of $-0,388$ that whenever religiosity $1 \%$ increased it will lower the hedonistic lifestyle of 0,388\%. Regression coefficient $(B)$ socio-economic status of parents of 1,539 that which means when the value socio-economic status of parents increases the lifestyle of hedonism 1\% adolescent also rise 1,539\%. Lifestyle of hedonism in adolescents of $24,2 \%$ can be caused by the influence of religiosity and socio-economic status of parents with $R=0,492^{a}$, and $R$ Square $=24,2 \%$, while $75,8 \%$ can be caused by other variables.
\end{abstract}

Keywords: Religiosity, socioeconomic status, lifestyle of hedonism. 


\section{PENDAHULUAN}

Masa remaja adalah masa-masa krisis identitas atau masa pencarian identitas diri, pada masa mencari jati diri, remaja mencobacoba dengan berbagai peran (Sumanto,2014).

Masa remaja tidak jauh dengan gaya hidup hedonisme/Hedone (kenikmatan atau kesenangan) diperoleh dengan memuaskan keinginannya, yang dimiliki rata-rata remaja Indonesia bisa jadi karena pengaruh publik figur luar negeri atau dalam negeri seperti banyaknya artis remaja mengoleksi mobil mewah,, serta tayangan-tanyangan televisi lainnya yang penuh dengan Hedonisme.

Remaja yang dimaksud didalam penelitian ini adalah remaja awal (early adolencence) kurang lebih berlangsung dimasa sekolah menengah pertama dan sekolah menengah atas dan perubahan pubertas terbesar dimasa ini (Santrock, 2007:20), atau sekitar usia 13-14 tahun sampai 16-17 tahun menurut Elizabeth B Hurlock dalam Sumanto (2014:76). Hal ini dapat peneliti temukan dibeberapa Sekolah Menengah Atas (SMA) Dan Sekolah Menengah Kejuruan (SMK) serta Madrasah Aliyah Negeri di Samarinda, tidak sedikit remaja yang memiliki handphone, jam tangan, tas dan sepatu sekolah mahal bahkan ada yang sudah mengendarai mobil.

Fenomena serupa dapat dilihat dibeberapa cafe, bioskop, tempat karaoke, dan tempat hiburan lainnya banyak dari mereka yang suka ngumpul sampai tengah malam. Gaya hidup mereka terlihat penuh dengan kesenangan, apa mereka semua dari keluarga mampu dan berapa uang saku mereka sehingga bisa memiliki kemudahan dalam mode maupun ketempat hiburan.

Setiap individu memiliki sisi hedonisme, begitu juga dengan remaja, tergantung cara dan tingkat pemenuhannya sesuai dengan yang dikemukakan Mower\&Minor (2002:221) hedonisme adalah keinginan untuk mengalami emosi, merujuk pada perolehan kesenangan melalui perasaan. Orang yang bersifat hedonik untuk mencari berbagai pengalaman emosi, termasuk rasa cinta, benci, takut, sedih, marah, muak. Pada awalnya mungkin terlihat ganjil bahwa orang mencari pengalaman yang negatif. Namun, real coaster dibuat untuk menciptakan rasa takut. Banyak orang pula yang kebioskop atau membaca buku untuk memperoleh emosi positif dan negatif sekaligus seperti cinta, kesenangan, dan rasa takut. Seorang pria yang membeli seikat bunga untuk kekasihnya seharga lima puluh dolar hanya untuk layu dalam dua hari.

Status sosial ekonomi orang tua juga memiliki peran penting dalam gaya hidup hedonisme remaja. Status sosial ekonomi atau biasa disingkat SES (Socioeconomic Status) didenifisikan sebagai kelompok orang yang memiliki pekerjaan, pendidikan, dan karakteristik ekonomi yang kurang lebih sama. Di dalam Status sosial ekonomi terkandung sejumlah kualitas yang tidak setara. (Santrock, 2007:198).

Beberapa remaja yang memiliki orang tua kaya dan memiliki pekerjaan yang bergengsi, para remaja ini hidup dirumah dan lingkungan yang bagus, berlibur keluar negeri, menginap dihotel berkualitas, serta bersekolah ditempat yang murid-muridnya kebanyakan memiliki latar belakang sosial-ekonomi menengah keatas (Santrock, 2007:199). Gaya hidup hedonisme bukan hanya dimiliki remaja yang status sosial ekonomi orang tuanya menengah keatas tapi remaja yang status sosial ekonomi orang tuanya rendah juga banyak memiliki gaya hidup hedonisme, anak remaja mereka rela tidak membelanjakan uang sakunya berbulan-bulan demi membeli handphone, jam, tas, sepatu yang mahal atau menonton konser. Padahal secara fungsi sama saja dengan barang yang lebih murah. Remaja menjadikan sekolah ajang persaingan merk, bukan lagi bersaing secara akademik. Kebanyakan dari remaja hanya mengikuti trend yang sedang digemari bukan dari manfaat pembelian sebuah barang atau produk tersebut.

Hal tersebut dapat dilihat dari data survey yang dirilis tahun 2013 oleh lembaga perlindungan konsumen. Menunjukkan adanya permintaan barang-barang mewah yang cukup signifikan yang sebelumnya 3,6\% menjadi $19 \%$ dari total permintaan barang selama tahun 2013, belum lagi kenyataan bahwa subyek kebanyakan merupakan kalangan menengah kebawah (berpenghasilan ${ }^{\mathrm{Rp}} .800 .000$,- sampai Rp. 3.000.000,- perbulan) menunjukkan adanya kecendrungan masyarakat kelas menengah menjadi konsumtif. Hal ini diperparah dengan data tahun 2013 dari Marknetter's yang menyatakan bahwa penggerak ekonomi pasar website jual beli online merupakan kaum muda dengan rincian remaja berumur 17-19 tahun menempati urutan pertama (34\%), dilanjutkan netizen berumur 20-28 tahun (27\%), kemudian berumur 28-35 tahun (21\%), dan diatas 35 
tahun (18\%). Dari sini pasar online sangat bergantung dari budaya konsumsi dari netizen berusia relative muda (Syamila, 2015).

Gaya hidup hedonisme remaja bukan hanya dilihat dari status sosial ekonomi orang tua saja, tapi juga religiusitas remaja sendiri. Religiusitas adalah bentuk penghayatan dari keimanan seseorang kepada Tuhannya dari ketaatan ibadah dan perilakunya sehari-hari.

Religiusitas remaja dapat dilihat bagaimana remaja memahami nilai-nilai yang berlaku dalam aturan agama, memahami makna, sesuai aturan yang berlaku dalam aturan agama, rajin ibadah (sembahyang), bisa juga dengan melihat pernah tidaknya mengenyam pendidikan disekolah berlatar belakang agama, dibesarkan dan dididik keluarga dengan pola asuh yang lebih mengutamakan nilai-nilai agama. Tinggi rendahnya religiusitas pada remaja secara tidak langsung membentuk. Tetapi tidak menutup kemungkinan remaja yang memiliki religiusitas yang baik juga mempunyai gaya hidup hedonisme, entah itu hedonisme karena gaya hidup mereka atau karena orang tuanya saja yang suka membelikan barang berkualitas dan memberi kartu kredit. Bagi remaja, agama memiliki arti yang sama pentingnya dengan moral. Dibandingkan dengan masa anak-anak misalnya, keyakinan agama remaja telah mengalami perkembangan yang cukup berarti. Kalau masa anak-anak ketika mereka baru memilik kemampuan berpikir simbolik, Tuhan dibayangkan sebagai person dibawah awan, maka pada masa remaja mereka mungkin berusaha mencari sebuah konsep yang lebih mendalam tentang tuhan dan eksistensi. Perkembangan pemahaman agama terhadap keyankinan beragama ini sangat dipengaruhi perkembangan kognitifnya (Desmita, 2008:208).

Perasaan beragama remaja kepada Tuhannya bukanlah tetap, stabil akan tetapi adalah perasaan yang tergantung pada perubahan-perubahan emosi yang sangat cepat, terutama pada masa remaja pertama. Kebutuhan akan Allah SWT dibutuhkan apabila mereka dalam keadaan gelisah, karena menghadapi musibah atau bahaya yang mengancam, ketika ia takut gagal atau mungkin merasa berdosa. Dengan demikian, perasaan remaja terhadap Tuhannya bersifat ambivalensi, kadang-kadang cinta dan percaya kepada-Nya, tetapi sering juga berubah acuh tah acuh bahkan menentang (Sururin, 2004:69).

\section{METODE PENELITIAN}

Metode penelitian ini adalah Metode penelitian kuantitatif. Tujuan penelitian kuantitatif Menurut Indrawan dan Yaniawati (2014:51) adalah mendapatkan penjelasan tentang besarnya kebermaknaan (significance) dalam model yang dihipotesiskan sebagai jawaban atas masalah yang telah dirumuskan, Karena pembuktian bersifat matematis, dalam penelitian kuantitatif perlu diperhatikan tiga hal yakni pendefinisian, pengukuran dan pengujian. Subjek

Populasi dalam penelitian ini adalah seluruh siswa dan siswi kelas XI sebesar 229 siswa di MAN 1 Samarinda, sedangkan Sampel dalam penelitian ini sebanyak 82 subjek.

\section{HASIL DAN PEMBAHASAN}

\section{Uji Normalitas}

Kolom distribusi data religiusitas terdapat Kolmogorov-Smirnov $=1,049$ dan probabilitas 0,222 $\geq 0,05$ (Asymp. Sig. (2tailed)). Oleh karena $\mathrm{p}=0,222$ atau $\mathrm{p} \geq$ 0,05 ,maka diketahui bahwa data variabel pada 82 sampel adalah normal atau memenuhi persyaratan uji normalitas (Triton, 2006:79). Dan Kolom distribusi data status sosial ekonomi orang tua terdapat KolmogorovSmirnov $=1,108$ dan probabilitas $0,172 \geq 0,05$ (Asymp. Sig. (2-tailed)). Oleh karena $\mathrm{p}=0,172$ atau $\mathrm{p} \geq 0,05$,maka diketahui bahwa data variabel pada 82 subjek adalah normal atau memenuhi persyaratan uji normalitas (Triton,2006:79).

\section{Metode Regeresi Berganda}

Interpretasi pada coefficients nilai $\mathrm{B}$ constant 44,819 dari kedua variabel independen nilai B religiusitas dan B status sosial ekonomi orang tua yang signifikan atau berpengaruh dapat dibuat persamaan regresi sebagai berikut : $\mathrm{Y}=\mathrm{a}+\mathrm{b} 1 \mathrm{X} 1+\mathrm{b} 2 \mathrm{X} 2=44,819-388 \mathrm{X} 1+1,539$ $\mathrm{X} 2$

Keterangan :

$\mathrm{Y}=$ Hedonisme $\mathrm{a}=$ Konstanta

$\mathrm{X} 1=$ Religiusitas $\mathrm{X} 2=$ Status sosial ekonomi

Dasar pengambilan keputusan untuk mengetahui koefisien pengaruh masing-masing variabel berdasarkan nilai $t_{\text {hitung }}$ dengan melihat derajat bebas $(\mathrm{db})=\mathrm{N}-\mathrm{k}, \mathrm{N}($ Jumlah sampel $)=$ 
82, dan $\mathrm{K}($ Jumlah Variabel $)=3$, sehingga $\mathrm{db}=$ $82-3=79 . t_{\text {tabel }}(\mathrm{db}=79$ taraf kepercayaan $95 \%$ $(\mathrm{t}=\alpha / 2=5 \% / 2=0,025)$ sehingga diperoleh $\mathrm{t}_{\text {tabel }}$ 0,$025 ; 79$ jadi $t_{\text {tabel }}$ adalah 2,000 .

$t_{\text {hitung }} \mathrm{X} 1-2.798$ (+ dan - diabaikan karena uji bersifat 2 sisi), oleh Karena $t_{\text {hitung }} \geq$ $\mathrm{t}_{\text {tabel}}$, maka $\mathrm{H}_{0}$ ditolak atau religiusitas secara signifikan berpengaruh terhadap gaya hidup hedonisme pada remaja, sehingga hipotesis yang menduga bahwa semakin religiusitas tinggi akan menyebabkan gaya hidup hedonisme pada remaja turun diterima.

$t_{\text {hitung }} X 24,580$, oleh Karena $t_{\text {hitung }} \geq t_{\text {tabel }}$, maka $\mathrm{H}_{0}$ ditolak atau status sosial ekonomi orang tua secara signifikan berpengaruh terhadap gaya hidup hedonisme pada remaja, sehingga hipotesis yang menduga bahwa semakin status sosial ekonomi meningkat akan menyebabkan gaya hidup hedonisme pada remaja meningkat diterima.

Berdasarkan nilai probabilitas X1: $\mathrm{p}=$ 0.007 , oleh karena $\mathrm{p} \leq 0,05$; maka $\mathrm{H}_{0}$ ditolak, atau religiusitas secara signifikan berpengaruh terhadap gaya hidup hedonisme pada remaja. $\mathrm{X} 2: \mathrm{p}=0.000$, oleh karena $\mathrm{p} \leq 0,05 ;$ maka $\mathrm{H}_{0}$ ditolak, atau status sosial ekonomi orang tua secara signifikan berpengaruh terhadap gaya hidup hedonisme pada remaja.

Melihat nilai Koefisien Korelasi (R) dari variabel independen yaitu Religiusitas dan Status sosial ekonomi orang tua dengan variabel dependen yaitu Gaya hidup hedonisme pada remaja menunjukan tingkat yang cukup berpengaruh karena $\mathrm{R} 0,492^{\mathrm{a}} \leq 0,5$. Koefisien Determinasi ( $R$ Square) antara variabel $\mathrm{X} 1$ dan $\mathrm{X} 2$ terhadap variabel $\mathrm{Y}$ adalah sebesar $24,2 \%$.

Hal ini menunjukkan bahwa Gaya hidup hedonisme pada remaja dapat dijelaskan oleh $24,2 \%$ sebab religiusitas dan status sosial ekonomi orang tua, sedangkan sisanya $74,6 \%$ dapat disebabkan oleh sebab lain.

Berdasarakan analisis diatas peneliti memiliki kesimpulan bahwa religiusitas dan status sosial ekonomi mempengaruhi gaya hidup hedonisme pada remaja.

Hasil analisis berdasarkan regresi berganda bahwa religiusitas secara signifikan berpengaruh terhadap gaya hidup hedonisme pada remaja.

Religiusitas adalah bentuk penghayatan dari keimanan seseorang kepada Tuhannya dari ketaatan ibadah dan perilakunya sehari-hari. Berdasarkan kategorisasi jenjang (ordinal) menunjukan religiusitas termasuk kategori "sedang" dan skor sebesar 73\%, yang berarti
73\% siswa MAN 1 Samarinda memiliki tingkat religiusitas sedang. Sedangkan sumbangan pengaruh religiusitas terhadap gaya hidup hedonisme menurut analisis persamaan regresi berganda Koefisien regresi (B) religiusitas 0,388 atau sebesar $0,388 \%$.

Hasil analisis terhadap religiusitas dinyatakan bahwa religiusitas mempunyai pengaruh atau korelasi negatif terhadap gaya hidup hedonisme pada remaja yang artinya semakin tinggi religiusitas maka gaya hidup hedonisme pada remaja akan menurun, begitu pula sebaliknya.

Perasaan beragama remaja kepada Tuhannya bukanlah tetap, stabil akan tetapi adalah perasaan yang tergantung pada perubahan-perubahan emosi yang sangat cepat, terutama pada masa remaja pertama. Kebutuhan akan Allah SWT dibutuhkan apabila mereka dalam keadaan gelisah, karena menghadapi musibah atau bahaya yang mengancam, ketika ia takut gagal atau mungkin merasa berdosa. Dengan demikian perasaan remaja terhadap Tuhannya bersifat ambivalensi, kadang-kadang cinta dan percaya kepada-Nya, tetapi sering juga berubah acuh tah acuh bahkan menentang (Sururin, 2004:69). Sehingga tugas kita sebagai orang tua dan guru disekolah meningkatkan religiusitas remaja tersebut agar sebagai kontrol perilaku remaja agar tidak menyimpang dari norma agama dan masyarakat. Apabila remaja berada dalam lingkungan religiusitas yang baik, maka remaja dapat mengontrol gaya hidup hedonisme.

Status sosial ekonomi atau biasa disingkat SES (Socioeconomic Status) didenifisikan sebagai kelompok orang yang memiliki pekerjaan, pendidikan, dan karakteristik ekonomi yang kurang lebih sama. Di dalam Status sosial ekonomi terkandung sejumlah kualitas yang tidak setara. (Santrock, 2007:198).

Berdasarkan kategorisasi jenjang (ordinal) menunjukan status sosial ekonomi orang tua kategori "sedang" dan skor sebesar $70 \%$, yang maksudnya orang tua siswa MAN 1 Samarinda mempunyai status sosial ekonomi menengah sebesar 70\%. Sedangkan sumbangan pengaruh status sosial ekonomi orang tua terhadap gaya hidup hedonisme menurut analisis persamaan regresi berganda Koefisien regresi (B) status sosial ekonomi orang tua sebesar $1,539 \%$.

Berdasarkan pada pengajuan hipotesis didapatkan hubungan positif antara perhatian 
status sosial ekonomi orang tua dengan gaya hidup hedonisme pada remaja siswa kelas XI MAN 1 Samarinda.

Analisis diatas dideskripsikan bahwa semakin meningkat status sosial ekonomi orang tua maka semakin tinggi pula gaya hidup hedonisme pada remaja, begitu pula sebaliknya. Hal ini dapat dilihat dari hasil analisis Korelasi pearson, analisis regresi berganda diatas, mulai dari persamaan regresi, berdasarkan nilai $t_{\text {hitung, }}$, hingga berdasarkan nilai probability.

Menurut Wells dan Tiger dalam Rianton (2011) gaya hidup atau life style adalah pola hidup, penggunaan uang dan waktu yang dimiliki seseorang. Gaya hidup hedonisme pada remaja adalah perilaku remaja yang menggunakan uang dan memanfaatkan waktunya untuk kesenangan demi memenuhi pemuasan perasaannya.

Berdasarkan kategorisasi jenjang (ordinal) menunjukan sumbangan gaya hidup hedonisme pada remaja termasuk kategori "sedang" dan skor sebesar 67\%. Hal ini menunjukkan bahwa 67\% siswa MAN 1 Samarinda memiliki gaya hidup hedonisme pada level sedang. Sedangkan menurut analisis persamaan regresi berganda nilai gaya hidup hedonisme pada remaja sebesar 44,819 atau $45 \%$, bila nilai religiusitas dan status sosial ekonomi orang tua sebesar 0 (nol).

\section{KESIMPULAN}

Berdasarkan hasil analisa dan pengujian hipotesis serta pembahasan, maka dapat ditarik kesimpulan sebagai berikut :

1. Religiusitas mempunyai hubungan yang negatif dengan gaya hidup hedonisme pada remaja, hal ini berarti bahwa semakin baik atau positif religiusitas remaja maka akan semakin menurun gaya hidup hedonisme pada remaja dan begitu pula sebaliknya.

2. Status sosial ekonomi orang tua mempunyai hubungan yang positif dengan gaya hidup hedonisme pada remaja di kelas XI MAN 1 Samarinda, hal ini berarti bahwa semakin baik atau positif status sosial ekonomi orang tua remaja maka akan semakin meningkat hedonisme pada remaja dan begitu pula sebaliknya.

3. Gaya hidup hedonisme pada remaja di kelas XI MAN 1 Samarinda dalam tingkatan sedang dikarenakan tingkat pengaruh religiusitas remaja yang cukup baik dan status sosial ekonomi orang tua menengah kebawah.

\section{DAFTAR PUSTAKA}

Budi, Triton Prawira., 2006.spss 13.00 Terapan; Riset Statistik Parametrik. CV. Andi Offset : Yogyakarta

Desmita, 2008. Psikologi Perkembangan. Cetakan ke-empat. PT. Remaja Rosdakarya: Bandung

Indrawan, R. \& Yaniawati, R.P., 2014. Metodologi Penelitian Kuantitatif, Kualitatif, dan Campuran untuk Manajemen, Pembangunan Dan Pendidikan. PT. Refika Aditama: Bandung.

Jalaludin, 2007. Psikologi Agama Edisi Revisi 2007, PT. Raja Grafindo Persada: Jakarta.

Mowen, Jonh. C \& Minor, Michael. 2002 coustumer behavior (lifestyle), $5^{\text {th }}$ ED Erlangga: Jakarta

Najati, M.U., 2005. Psikologi Dalam Al-Qur'an (Terapi Qur'ani Dalam Penyembuhan Gangguan Kejiwaan). Cetakan 1 (satu) CV. Pustaka Setia: Bandung.

Rianton., 2011. Hubungan antara konformitas kelompok teman sebaya dengan gaya hidup hedonis pada mahasiwa Kab. Dhamasraya di Yogyakarta. Jurnal Fakultas Psikologi Universitas Ahmad Dahlan Yogyakarta.

Saifi, S. dan Mehmood, T., 2011. Effects Of Socioeconomic Status On Students Achievement (International Journal of Social Sciences and Education Volume: 1 Issue: 2 April 2011). Assistant Professor University of Gujrat and Principal, Government Centennial Model High School Turbela Township Haripur.

Santrock, J. W. 2007. Remaja. Judul asli Adolenscence, eleventh edition. Penerbit Airlangga: Jakarta

Schiffman, L. \& Kanuk, L. L.2007. perilaku konsumen edisi terjemahan. PT. Indeks : Jakarta

Sumanto, 2014. Psikologi Perkembangan, Fungsi Dan Teori. Cetakan pertama, penerbit CAPS (Center of Academic Publishing Service): yogyakarta 
Sururin, M. Ag., 2004. Ilmu jiwa Agama. PT: Rajagrafindo Persada: Jakarta

Syamila, A., 2015. Saat Perilaku Konsumtif Menjadi Budaya Remaja. Dipublish 20 Desember 2014 dan di Update $\quad 17 \quad$ Juni 2015 Http//Ahdasyamila.M.Kompasiana.Com/Ahdasyamil.C om/Saat-Perilaku-Konsumtif-Menjadi-Budaya-Remaja. Diunduh 14 September 2015, Pukul 13.45 WITA

Syafaati, A., Lestari, R., \& Asyanti, S., 2008. Dugem: Gaya Hidup Hedonisme dikalangan Anak Muda (Indigenous Jurnal Ilmiah Psikologi Vol. 10, No.2: 2-15, ISN 0854-2880). Fakultas Psikologi Universitas Muhammadiyah Surakarta.
Tirmidi dan Rambe., 2010. Korelasi Antara Dukungan Sosial Orang Tua dan Self-Directed Learning pada siswa SMA. Jurnal Fakultas Psikologi Universitas Sumatera Utara. Vol. 37, No.2, Desember 2010: 216-223

Utami., 2012. dengan judul Religiusitas, Koping Religius, dan Kesejahteraan Subjektif dari. Jurnal Fakultas Psikologi Universitas Gadjah Mada. Volume 39, No. 1, Juni 2012: 46 -66 .

Wibisono, S., 2012. Orientasi keberagaman, modal sosial dan prasangka terhadap kelompok agama lain pada mahasiswa muslim. Jurnal Program Studi Psikologi Universitas Islam Indonesia Yogyakarta. Vol. 14 No. 03, Desember 2012. 